ISSN 2073-4441

www.mdpi.com/journal/water

Review

\title{
Constructed Wetlands for Wastewater Treatment
}

\section{Jan Vymazal}

Department of Landscape Ecology, Faculty of Environmental Sciences, Czech University of Life Sciences, Prague, Náměstí Smiřických 1, 28163 Kostelec nad Černými lesy, Czech Republic; E-Mail: vymazal@knc.czu.cz; Tel.: +420 224386 204; Fax: +420 224386202

Received: 2 July 2010; in revised form: 12 August 2010 / Accepted: 20 August 2010 /

Published: 27 August 2010

\begin{abstract}
The first experiments using wetland macrophytes for wastewater treatment were carried out in Germany in the early 1950s. Since then, the constructed wetlands have evolved into a reliable wastewater treatment technology for various types of wastewater. The classification of constructed wetlands is based on: the vegetation type (emergent, submerged, floating leaved, free-floating); hydrology (free water surface and subsurface flow); and subsurface flow wetlands can be further classified according to the flow direction (vertical or horizontal). In order to achieve better treatment performance, namely for nitrogen, various types of constructed wetlands could be combined into hybrid systems.
\end{abstract}

Keywords: constructed wetlands; macrophytes; nutrients; organics; wastewater

\section{Introduction}

Constructed wetlands (CWs) are engineered systems that have been designed and constructed to utilize the natural processes involving wetland vegetation, soils, and the associated microbial assemblages to assist in treating wastewaters. They are designed to take advantage of many of the same processes that occur in natural wetlands, but do so within a more controlled environment. CWs for wastewater treatment may be classified according to the life form of the dominating macrophyte, into systems with free-floating, floating leaved, rooted emergent and submerged macrophytes [1]. Further division could be made according to the wetland hydrology (free water surface and subsurface systems) and subsurface flow CWs could be classified according to the flow direction (horizontal and vertical) [2]. A simple scheme for various types of constructed wetlands is shown in Figure 1. 
Figure 1. The major characteristics of various types of constructed wetlands for wastewater treatment. $\mathrm{H}=$ horizontal, $\mathrm{V}=$ vertical.

\begin{tabular}{|l|l|l|l|}
\hline Vegetation & Submerged & Emergent \\
\hline $\begin{array}{l}\text { Water level in relation } \\
\text { to the surface }\end{array}$ & Above & Above & Felow \\
\hline Direction of flow & $\mathrm{H}$ & $\mathrm{H}$ & Above \\
\hline
\end{tabular}

The first experiments aimed at the possibility of wastewater treatment by wetland plants were undertaken by Käthe Seidel in Germany in the early 1950s at the Max Planck Institute in Plön [3]. Seidel then carried out numerous experiments aimed at the use of wetland plants for treatment of various types of wastewater, including phenol wastewaters [4], dairy wastewaters [5] or livestock wastewater [6]. Most of her experiments were carried out in constructed wetlands with either horizontal (HF CWs) or vertical (VF CWs) subsurface flow, but the first fully constructed wetland was built with free water surface (FWS) in the Netherlands in 1967 [7]. However, FWS CWs did not spread substantially in Europe where subsurface flow constructed wetlands prevailed in the 1980s and 1990s [2].

In North America, FWS CWs started with the ecological engineering of natural wetlands for wastewater treatment at the end of the 1960s and beginning of the 1970s [8-10]. This treatment technology was adopted in North America not only for municipal wastewaters but all kinds of wastewaters [11]. Subsurface flow technology spread more slowly in North America but, at present, thousands of CWs of this type are in operation [11].

Various types of constructed wetlands may be combined in order to achieve higher treatment effect, especially for nitrogen. Hybrid systems comprise most frequently VF and HF systems arranged in a staged manner but, in general, all types of constructed wetlands could be combined in order to achieve more complex treatment efficiency [12].

\section{Main Characteristics of Various Types of Constructed Wetlands}

Various types of constructed wetlands differ in their main design characteristics as well as in the processes which are responsible for pollution removal. For the purpose of this paper, only FWS CWs with emergent macrophytes are considered. 


\subsection{Free Water Surface Constructed Wetlands}

A typical FWS CW with emergent macrophytes is a shallow sealed basin or sequence of basins, containing 20-30 cm of rooting soil, with a water depth of $20-40 \mathrm{~cm}$. Dense emergent vegetation covers a significant fraction of the surface, usually more than 50\% (Figure 2). Besides planted macrophytes, naturally occurring species may be present [13]. Plants are usually not harvested and the litter provides organic carbon necessary for denitrification which may proceed in anaerobic pockets within the litter layer.

Figure 2. A free water surface constructed wetland (FWS CW) for stormwater runoff in Woodcroft Estate near Sydney, NWS, Australia. Photograph taken by the author.

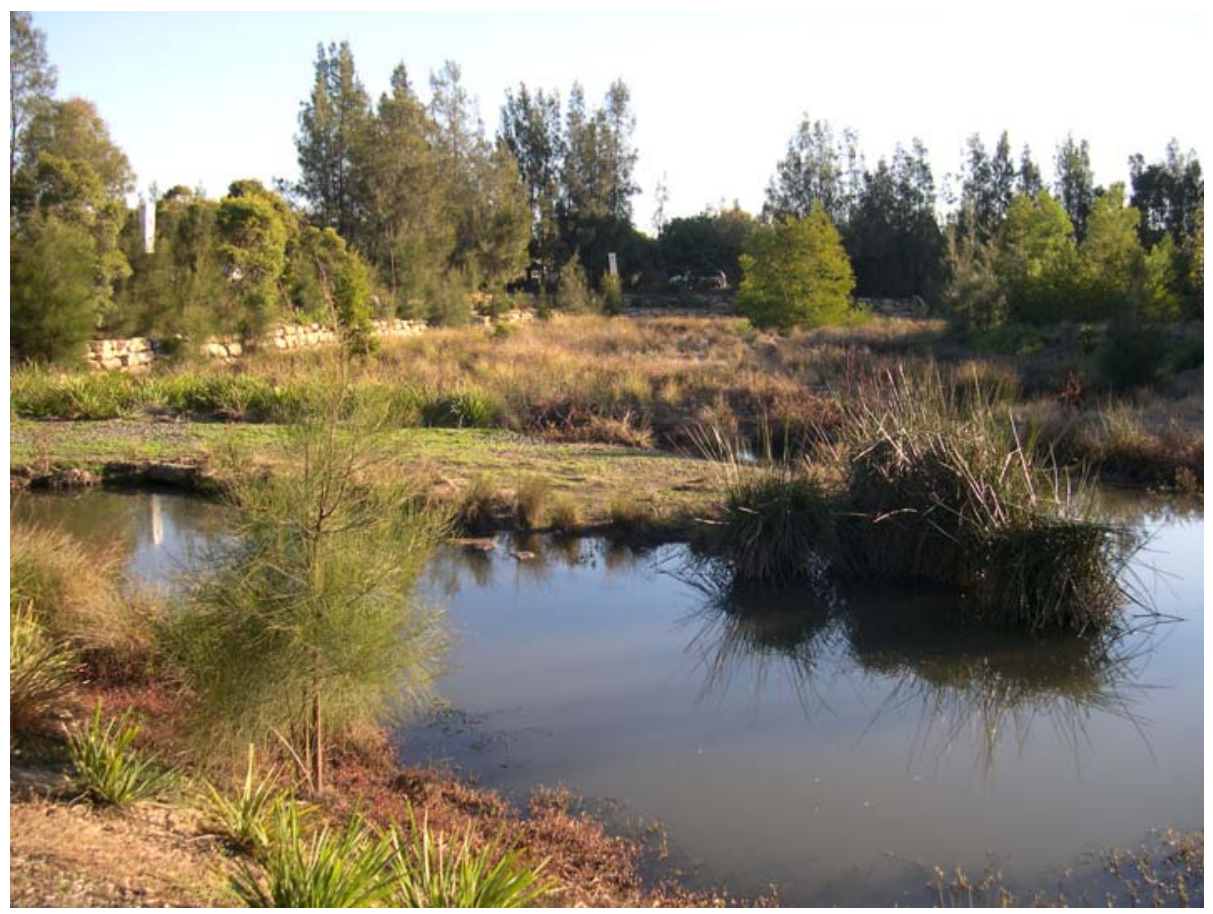

FWS CWs are efficient in removal of organics through microbial degradation and settling of colloidal particles. Suspended solids are effectively removed via settling and filtration through the dense vegetation. Nitrogen is removed primarily through nitrification (in water column) and subsequent denitrification (in the litter layer), and ammonia volatilization under higher $\mathrm{pH}$ values caused by algal photosynthesis. Phosphorus retention is usually low because of limited contact of water with soil particles which adsorb and/or precipitate phosphorus. Plant uptake represents only temporal storage because the nutrients are released to water after the plant decay [2,11]. Constructed wetlands with FWS are frequently used in North America [11] (Figure 3) and Australia [14] (Figure 4). In Europe, this technology has recently gained more attention, especially in Sweden and Denmark where these systems are used to eliminate nitrogen from diffuse pollution [15].

Besides municipal wastewater, FWS CWs with emergent vegetation have been used to treat various types of wastewaters (Table 1). 
Figure 3. A FWS CW for treatment of alkaline mine drainage waters in Monastery Run, Pennsylvania, U.S. Photograph taken by the author.

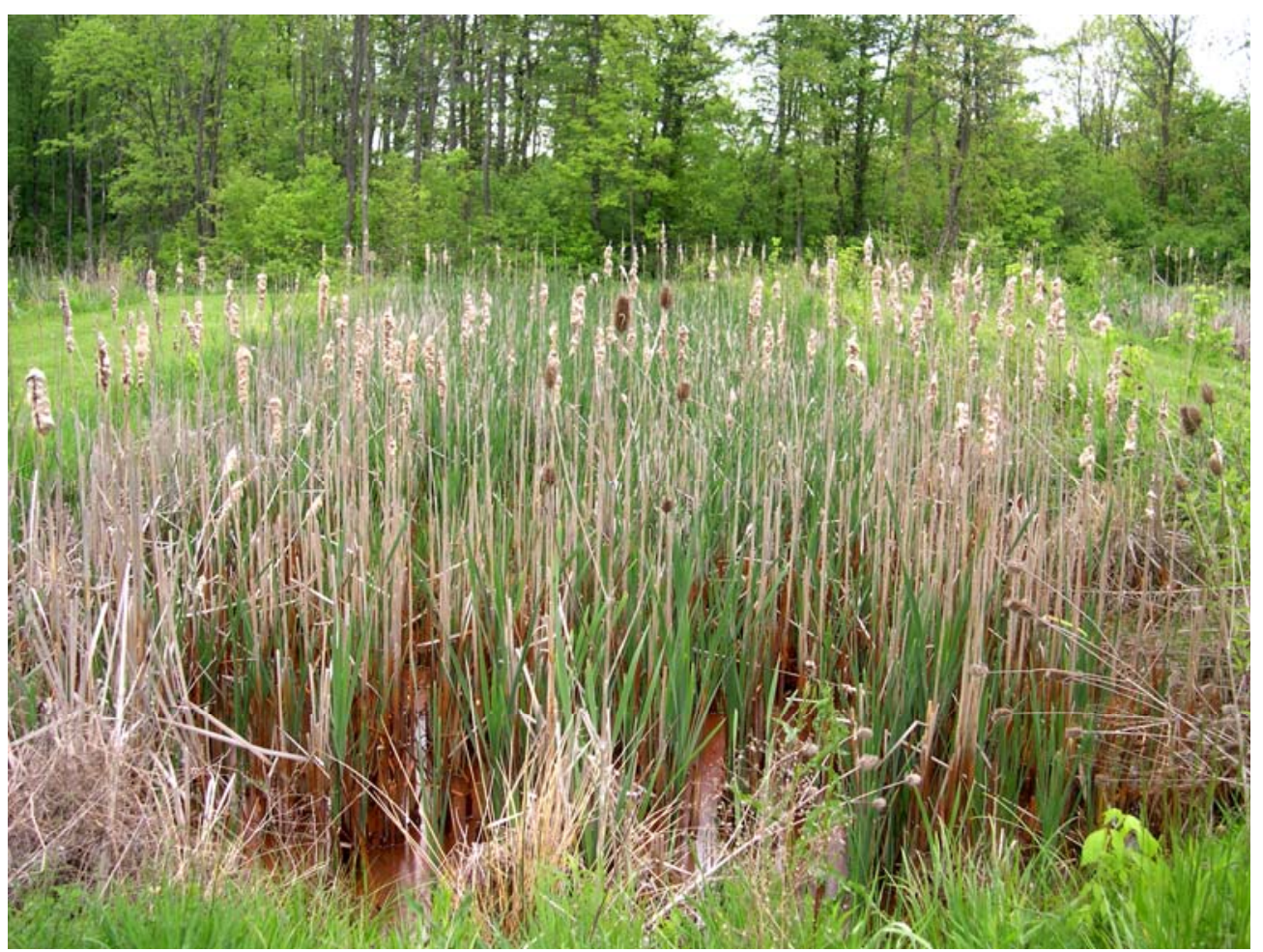

Figure 4. A FWS CW for tertiary treatment of municipal wastewater in McGrath Hill, Hawkesbury, near Sydney, NSW, Australia. Photograph taken by the author.

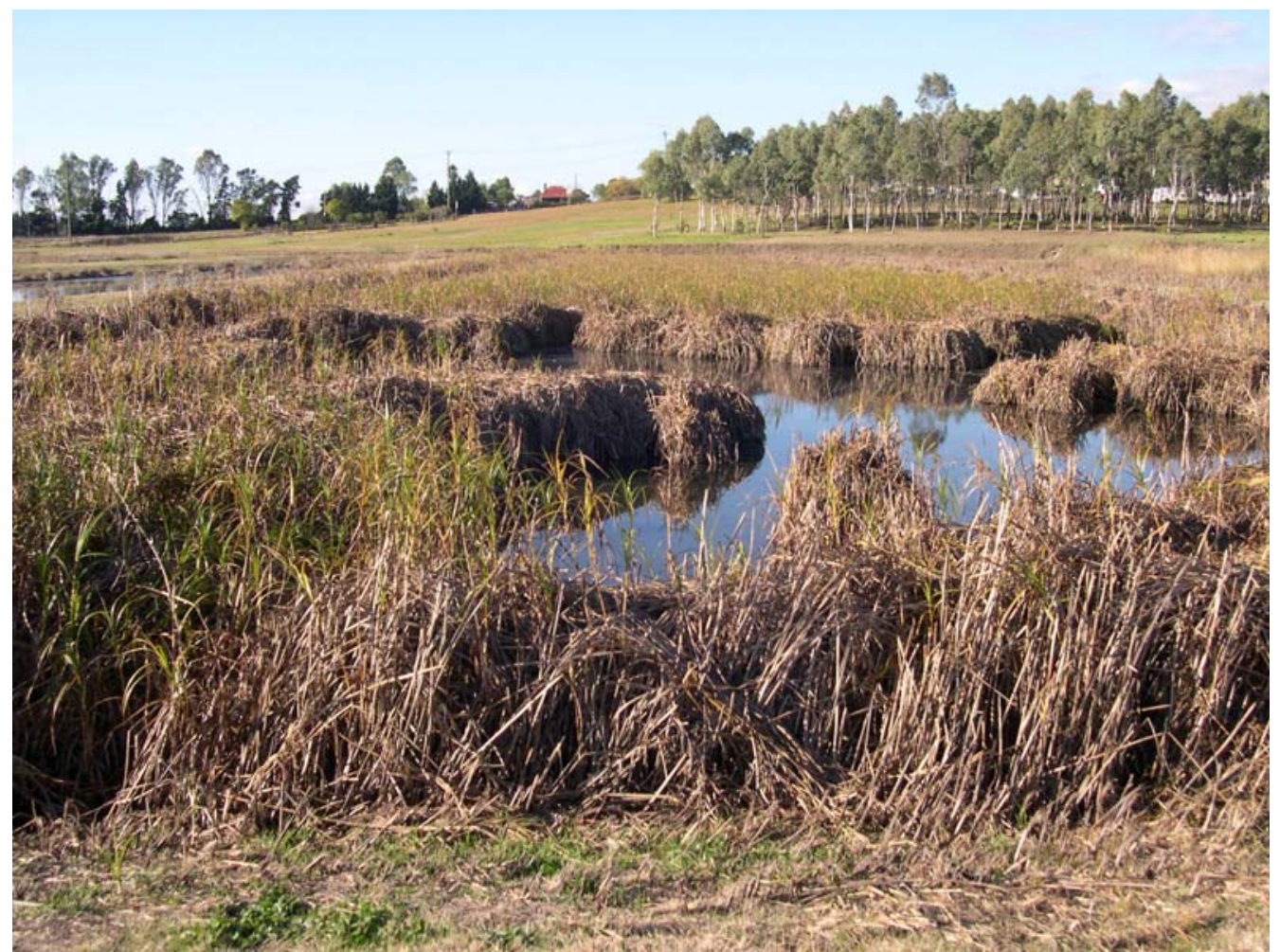


Table 1. Examples of the use of FWS CWs for various types of wastewater.

\begin{tabular}{lll}
\hline Type of wastewater & Location & Ref. \\
\hline Animal wastes & U.S. & {$[16-18]$} \\
Dairy pasture runoff & New Zealand & {$[19]$} \\
Agricultural drainage & U.S. & {$[20]$} \\
Stormwater runoff-residential & Australia & {$[21]$} \\
Stormwater runoff-highway & United Kingdom & {$[22]$} \\
Stormwater runoff-airport & Sweden & {$[23]$} \\
Acid coal mine drainage & U.S., Spain & {$[24,25]$} \\
Metal ores mine drainage & Germany, Ireland, Canada & {$[26-28]$} \\
Refinery process waters & U.S., Hungary & {$[29,30]$} \\
Paper and pulp wastewaters & U.S. & {$[31]$} \\
Shrimp aquaculture & U.S. & {$[32]$} \\
Landfill leachate & Sweden, Norway, U.S. & {$[33-35]$} \\
Sugar factory & Kenya & {$[36]$} \\
Olive mill & Greece & {$[37]$} \\
Woodwaste leachate & Canada & {$[38]$} \\
Metallurgic industry & Argentina & {$[39,40]$} \\
\hline
\end{tabular}

Sizing of FWS CWs is usually based either on volume or area. Volume-based methods use a hydraulic retention time to assess the pollutant removal while area-based methods assess pollutant reduction using the overall wetland area [41]. In Table 2, the basic sizing criteria for $\mathrm{BOD}_{5}$, TSS and TKN removal are given. Wallace and Knight [41] pointed out that FWS CWs are generally not effective for phosphorus removal and only inflow loading less than $0.1 \mathrm{~g} \mathrm{P} / \mathrm{m}^{2} \mathrm{~d}$ would provide low effluent concentrations.

Table 2. Loading rates recommended for achieving target effluent concentration in FWS CWs.

\begin{tabular}{llll}
\hline Parameter & Effluent & Loading rate & Ref. \\
\hline $\mathrm{BOD}_{5}$ & $30 \mathrm{mg} / \mathrm{L}$ & $6 \mathrm{~g} / \mathrm{m}^{2} \mathrm{~d}$ & {$[41,42]$} \\
& $25 \mathrm{mg} / \mathrm{L}$ & $3 \mathrm{~g} / \mathrm{m}^{2} \mathrm{~d}$ & {$[41]$} \\
& $20 \mathrm{mg} / \mathrm{L}$ & $4.5 \mathrm{~g} / \mathrm{m}^{2} \mathrm{~d}$ & {$[42]$} \\
\hline $\mathrm{TSS}$ & $30 \mathrm{mg} / \mathrm{L}$ & $7 \mathrm{~g} / \mathrm{m}^{2} \mathrm{~d}$ & {$[41]$} \\
& $30 \mathrm{mg} / \mathrm{L}$ & $5 \mathrm{~g} / \mathrm{m}^{2} \mathrm{~d}$ & {$[42]$} \\
& $25 \mathrm{mg} / \mathrm{L}$ & $3.5 \mathrm{~g} / \mathrm{m}^{2} \mathrm{~d}$ & {$[41]$} \\
& $20 \mathrm{mg} / \mathrm{L}$ & $3 \mathrm{~g} / \mathrm{m}^{2} \mathrm{~d}$ & {$[42]$} \\
\hline TKN & $10 \mathrm{mg} / \mathrm{L}$ & $1.5 \mathrm{~g} / \mathrm{m}^{2} \mathrm{~d}$ & {$[41]$} \\
\hline
\end{tabular}

\subsection{Constructed Wetlands with Horizontal Subsurface Flow}

HF CWs consist of gravel or rock beds sealed by an impermeable layer and planted with wetland vegetation (Figure 5). The wastewater is fed at the inlet and flows through the porous medium under the surface of the bed in a more or less horizontal path until it reaches the outlet zone, where it is collected and discharged. In the filtration beds, pollution is removed by microbial degradation and 
chemical and physical processes in a network of aerobic, anoxic, anaerobic zones with aerobic zones being restricted to the areas adjacent to roots where oxygen leaks to the substrate $[43,44]$.

This type of constructed wetland was developed in the 1950s in Germany by Käthe Seidel who designed the HF CWs using coarse materials as the rooting medium. In the 1960s, Reinhold Kickuth suggested soil media with high clay content and called the system the "Root Zone Method" [45]. In the early 1980s, the HF CWs technology was introduced to Denmark and by 1987 nearly 100 soil-based systems were put in operation [46]. Despite problems with surface flow soil-based systems exhibited high treatment effect for organics and suspended solids if reed bed area 3-5 $\mathrm{m}^{2} \mathrm{PE}^{-1}$ (population equivalent) was used [46]. During the late 1980s, the HF CWs were also introduced to other countries, such as Austria and United Kingdom [2] and then in the 1990s, this system spread into most European countries and also to North America, Australia, Asia and Africa. In the late 1980s, soil material was replaced by coarse material and at present, washed gravel or rock with grain size of about $10-20 \mathrm{~mm}$ are commonly used [2].

Organic compounds are effectively degraded mainly by microbial degradation under anoxic/anaerobic conditions as the concentration of dissolved oxygen in the filtration beds is very limited [47]. Suspended solids are retained predominantly by filtration and sedimentation and the removal efficiency is usually very high [2]. The major removal mechanism for nitrogen in HF CWs is denitrification. Removal of ammonia is limited due to lack of oxygen in the filtration bed as a consequence of permanent waterlogged conditions [48]. Phosphorus is removed primarily by ligand exchange reactions, where phosphate displaces water or hydroxyls from the surface of iron and aluminum hydrous oxides. Unless special materials are used, removal of $\mathrm{P}$ is usually low in HF CWs [48].

The most important roles of plants in HF CWs are provision of substrate (roots and rhizomes) for the growth of attached bacteria, radial oxygen loss (oxygen diffusion from roots to the rhizosphere), nutrient uptake and insulation of the bed surface in cold and temperate regions [49].

For a long time, the HF CWs have been designed using either simple "rule of thumb" set at $5 \mathrm{~m}^{2} \mathrm{PE}^{-1}$ or plug-flow first order models $[11,43]$. Recently, more complex dynamic, compartmental models [50,51] have been developed. However, in these models many parameters are difficult to measure and therefore many assumptions must be made. Hence, it is important to realize that more complex models do not necessarily bring more precise design parameters. However, no matter which design model is used, for municipal sewage, the area of HF CWs is usually about $5 \mathrm{~m}^{2} \mathrm{PE}^{-1}$ [2]. To achieve the outflow $\mathrm{BOD}_{5}$ and TSS concentration of $30 \mathrm{mg} / \mathrm{L}$, the U.S. EPA recommends the respective inflow loads of $6 \mathrm{~g} / \mathrm{m}^{2} \mathrm{~d}$ and $20 \mathrm{~g} / \mathrm{m}^{2} \mathrm{~d}$.

HF CWs have always been used to treat domestic (Figure 6) and municipal (Figure 7) wastewaters around the world. However, at present, HF CWs are used to treat many other types of wastewaters including industrial and agricultural, landfill leachate and runoff waters (Table 3). 
Figure 5. Schematic layout of a constructed wetland with horizontal subsurface flow. 1 inflow distribution zone filled with large stones; 2 impermeable layer; 3 filtration material; 4 vegetation; 5 water level in the bed; 6 outflow collection zone; 7 drainage pipe; 8 outflow structure with water level adjustment [44]. With permission from Backhuys Publishers.

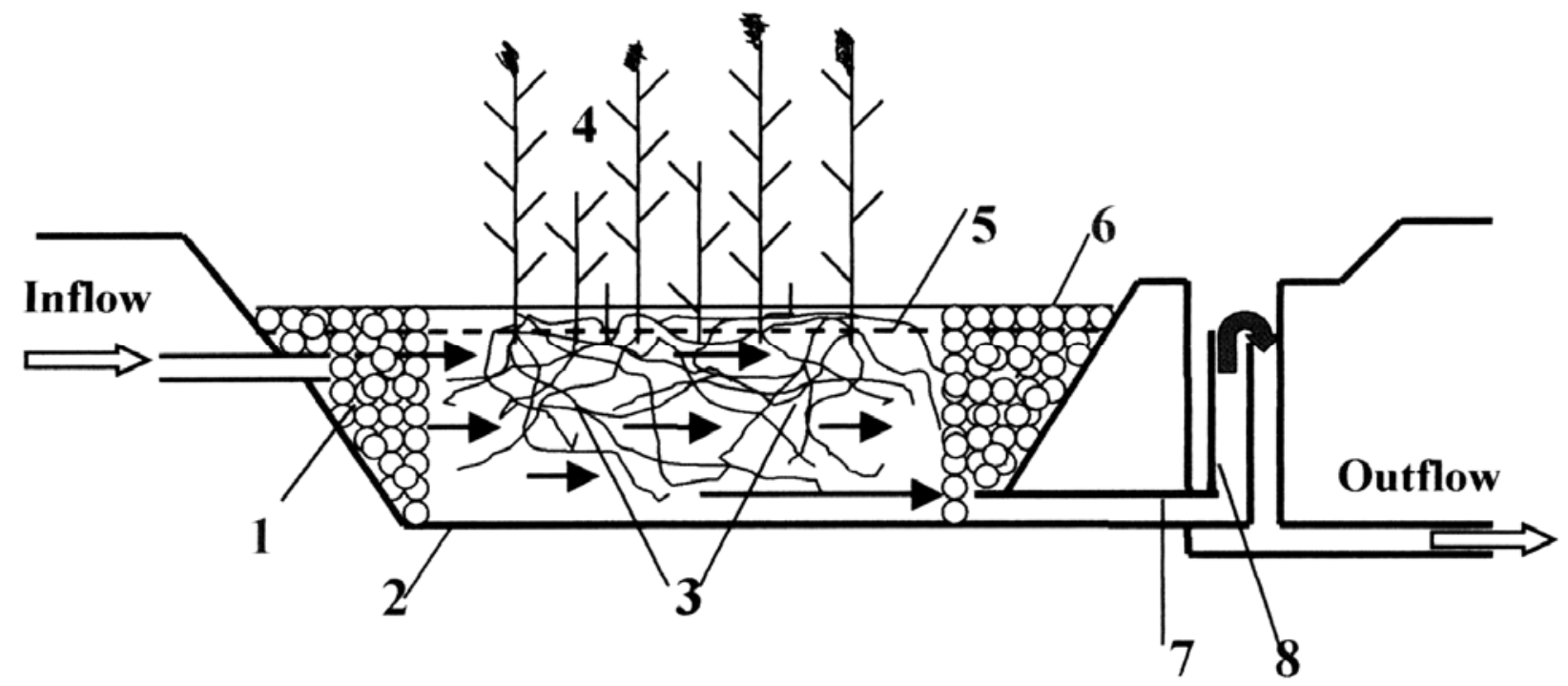

Figure 6. On-site horizontal flow (HF) CWs at Struhaře, Czech Republic, planted with Phalaris arundinacea and Iris pseudacorus. Photograph taken by the author.

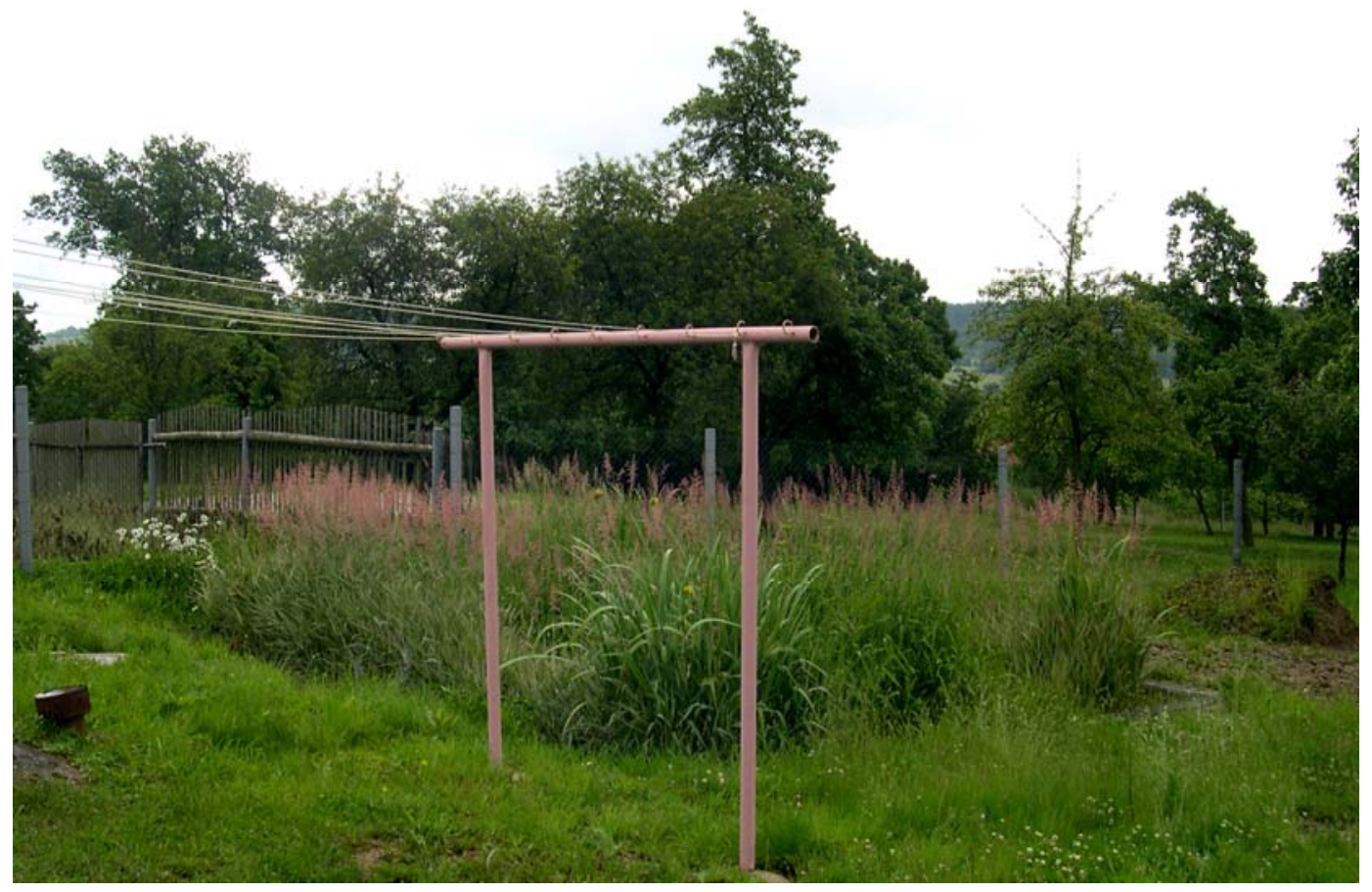


Figure 7. HF CWs at Staverton, United Kingdom. Tertiary treatment for 603 PE. Photograph taken by the author.

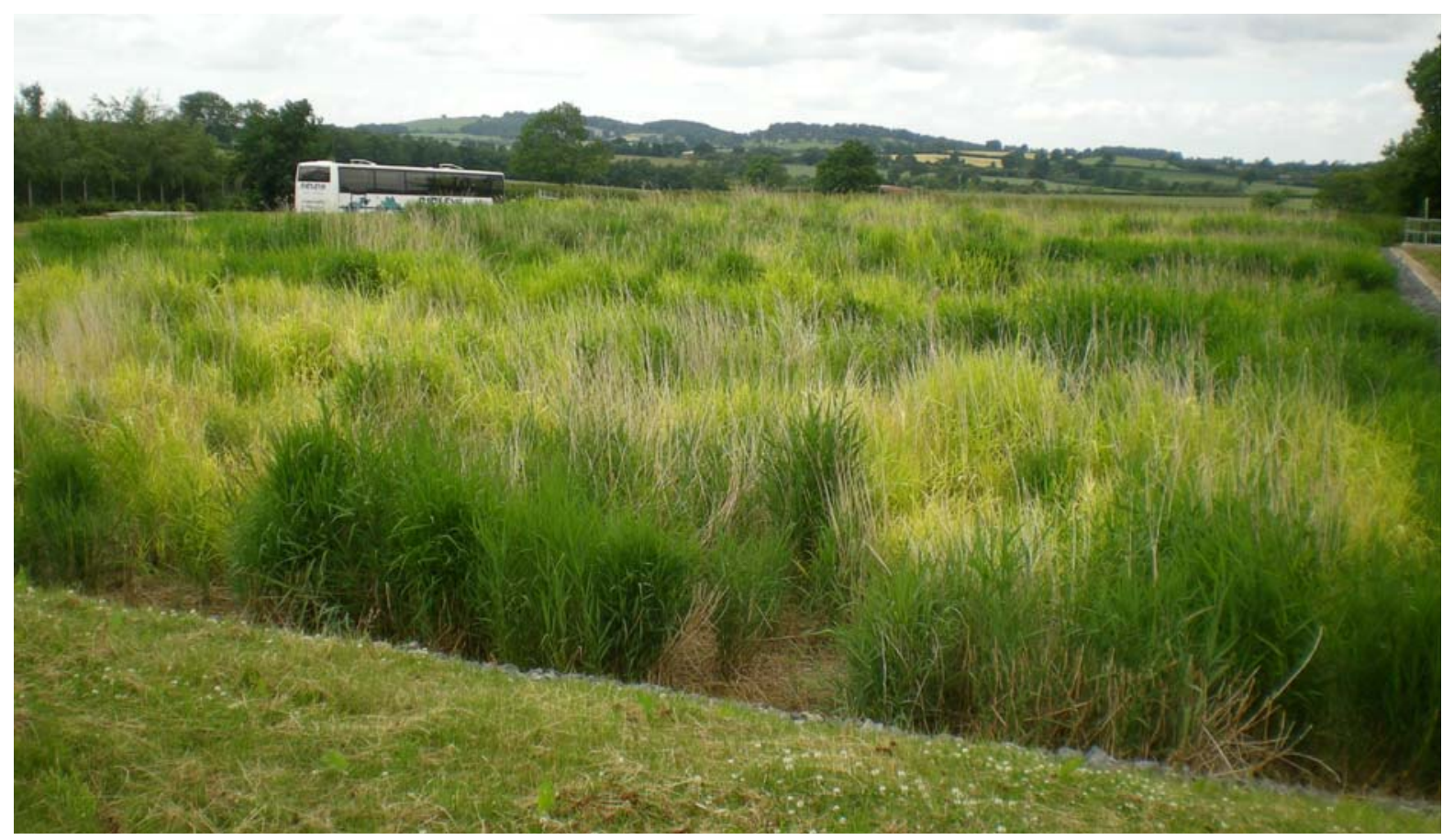

Table 3. Examples of the use of HF CWs for various types of wastewater.

\begin{tabular}{lll}
\hline Type of wastewater & Location & Ref. \\
\hline Petrochemical & U.S., China & {$[52,53]$} \\
Chemical industry & United Kingdom & {$[54]$} \\
Paper and pulp wastewaters & U.S. & {$[55]$} \\
Abattoir & Mexico, Ecuador & {$[56,57]$} \\
Textile industry & Australia & {$[58]$} \\
Tannery industry & Portugal & {$[59]$} \\
Food industry & Slovenia, Italy & {$[60,61]$} \\
Distillery and winery & India, Italy & {$[62,63]$} \\
Pig farm & Australia, Lithuania & {$[64,65]$} \\
Fish farm & Canada, Germany & {$[66,67]$} \\
Dairy & U.S., Germany, Uruguay & {$[68-70]$} \\
Highway runoff & United Kingdom & {$[71]$} \\
Airport runoff & U.S. & {$[72]$} \\
Nursery runoff & Australia & {$[73]$} \\
Landfill leachate & Poland & {$[74]$} \\
\hline
\end{tabular}

\subsection{Constructed Wetlands with Vertical Subsurface Flow}

Vertical flow constructed wetlands (VF CWs) (Figure 8) were originally introduced by Seidel to oxygenate anaerobic septic tank effluents [75]. However, the VF CWs did not spread as quickly as HF CWs probably because of the higher operation and maintenance requirements due to the necessity to pump the wastewater intermittently on the wetland surface (Figure 9). The water is fed in large 
batches and then the water percolates down through the sand medium. The new batch is fed only after all the water percolates and the bed is free of water. This enables diffusion of oxygen from the air into the bed. As a result, VF CWs are far more aerobic than HF CWs and provide suitable conditions for nitrification. On the other hand, VF CWs do not provide any denitrification. VF CWs are also very effective in removing organics and suspended solids. Removal of phosphorus is low unless media with high sorption capacity are used [2]. As compared to HF CWs, vertical flow systems require less land, usually 1-3 $\mathrm{m}^{2} \mathrm{PE}^{-1}$ [76-79]. The early VF CWs were composed of several stages with beds in the first stage fed in rotation. At present, VF CWs are usually built with one bed and the system is called "compact" VF CWs [77].

VF CWs are very often used to treat domestic and municipal wastewater and especially when discharge limits are set for ammonia-nitrogen. However, in the literature, numerous reports have been published on the use of VF CWS for various types of wastewater such as refinery effluent [80], composting leachate [81], airport runoff [82], dairy [83] or cheese production effluent [84].

Figure 8. Layout of a vertical flow constructed wetland system for a single household. Raw sewage is pre-treated in a sedimentation tank. Settled sewage is pulse-loaded onto the surface of the bed by a level-controlled pump. Treated effluent is collected in a system of drainage pipes, and half of the effluent is recirculated back to the pumping well (or to the sedimentation tank) [76]. With permission from Elsevier.

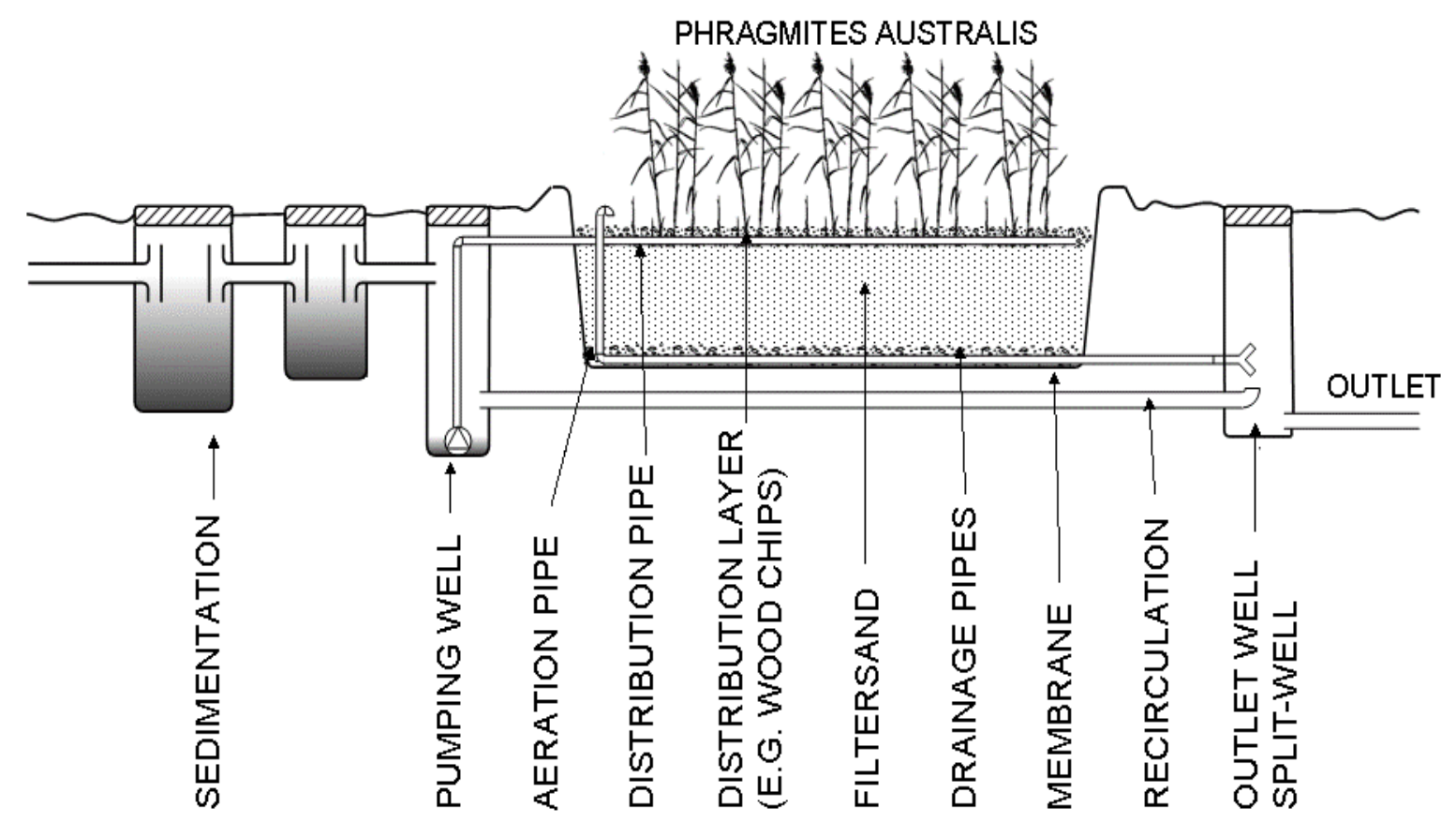

In upflow vertical CWs, the wastewater is fed on the bottom of the wetland. The water percolates upward and then it is collected either near the surface or on the surface of the wetland bed. These systems are commonly used, for example, in Brazil [85]. Recently, the "fill and drain" or "tidal" CWs have been developed. In tidal flow systems the wastewater percolates upwards until the surface is flooded. When the surface is completely flooded, the feeding is stopped, the wastewater is then held in the bed and, at a set time later, the wastewater is drained downwards. After the water has drained 
from the filtration bed, the treatment cycle is complete and air can diffuse into the voids in the filtration material [86].

Figure 9. Wastewater distribution at vertical flow (VF) CWs at Bexhill, NSW, Australia. Photograph taken by the author.

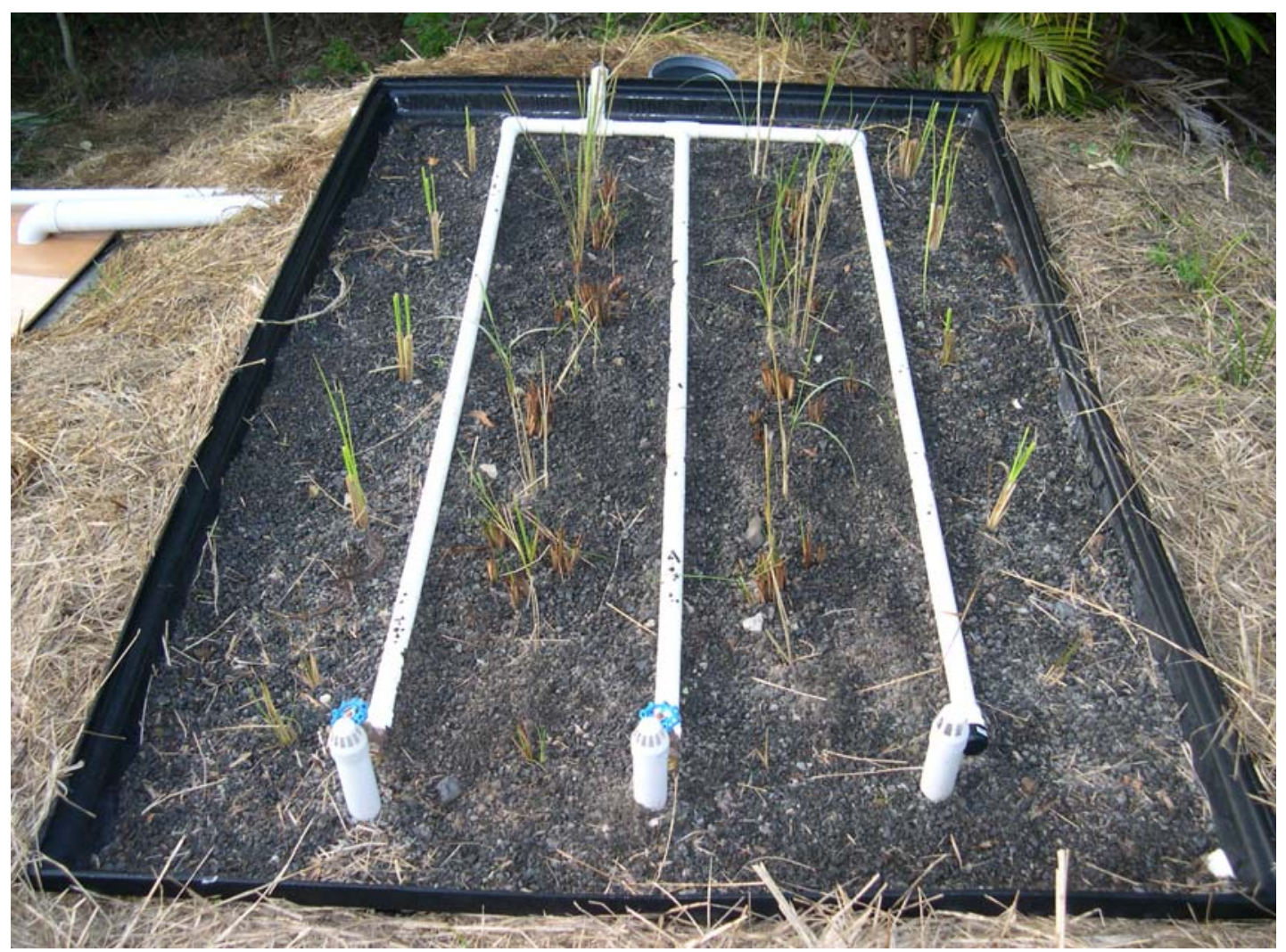

\subsection{Hybrid Constructed Wetlands}

Constructed wetlands could be combined in order to achieve a higher treatment effect by using advantages of individual systems. Most hybrid constructed wetlands combine VF and HF stages [87]. The VF-HF system was originally designed by Seidel as early as in the late 1950s and the early 1960s [71] but the use of hybrid systems was then very limited. In the 1980s VF-HF hybrid constructed wetlands were built in France [88] and United Kingdom [89]. At present, hybrid constructed wetlands are in operation in many countries around the world and they are used especially when removal of ammonia-N and total-N is required [2].

Besides sewage, hybrid constructed wetlands have been used to treat a variety of other wastewaters, for example, landfill leachate [90,91], compost leaching [92], slaughterhouse [93], shrimp and fish aquaculture $[94,95]$ or winery [63].

\section{Treatment Performance}

\subsection{Organics and Suspended Solids}

Removal of organics is high in all types of constructed wetlands (Table 4). While in FWS and VF constructed wetlands, the microbial degradation processes are mostly aerobic, in HF constructed 
wetlands, anoxic and anaerobic processes prevail. The treatment efficiency is similar for FWS and HF CWs, while for VF CWs the percentage efficiency is higher due to higher inflow concentrations. VF constructed wetlands are nearly always used for primary or secondary treatment while FWS are often used for tertiary treatment [96] and HF CWs are often used for treatment of wastewater diluted with stormwater runoff [2]. However, the outflow concentrations for secondary treatment systems are comparable for all types of constructed wetlands (Table 4). Removal of suspended solids is very high in all types of constructed wetlands (Table 4). The results presented in Table 4 also indicate that hydraulic retention time is usually lower in FWS CWs as compared to sub-surface flow CWs.

Table 4. Treatment efficiency (Eff, in \%) of various types of constructed wetlands (CWs) for organics and suspended solids. Inflow (In) and outflow (Out) concentrations in mg/L. $\mathrm{HLR}=$ hydraulic loading rate $(\mathrm{cm} / \mathrm{d}) . \mathrm{N}=$ number of $\mathrm{CWs} .{ }^{*}$ updated.

\begin{tabular}{lllllllccccc}
\hline Type of CW & Ref & \multicolumn{3}{c}{ BOD $_{\mathbf{5}}$} & \multicolumn{5}{c}{ TSS } \\
\hline & & In & Out & Eff & HLR & N & In & Out & Eff & HLR & N \\
\hline FWS & {$[2]^{*}$} & 161 & 42 & 74 & 4.1 & 50 & 185 & 43 & 77 & 4.8 & 52 \\
& {$[90]$} & 34.6 & 9.8 & 72 & 3.3 & 51 & 57.8 & 18.3 & 68 & 3.1 & 52 \\
\hline HF & {$[2]$} & 170 & 42 & 75 & 11.8 & 438 & 141 & 35 & 75 & 15.4 & 367 \\
\hline VF & {$[2]^{*}$} & 274 & 28 & 90 & 8.2 & 125 & 163 & 18 & 89 & 9.7 & 98 \\
\hline
\end{tabular}

Removal of nutrients in various types of constructed wetlands is presented in Table 5. Phosphorus retention is low in all types of constructed wetlands and CWs are seldom built with phosphorus being the primary target of the treatment. Most studies on phosphorus cycling in wetlands have shown that soil/peat accumulation is the major long-term phosphorus sink [97]. Among the various types of constructed wetlands, soil accretion occurs only in FWS CWs as the vegetation is not harvested and wastewater gets in contact with top soil layer. However, the magnitude of phosphorus retention is very low as compared to loads commonly occurring in wastewaters $[2,11,48]$. In sub-surface flow CWs, the major removal mechanisms are adsorption and precipitation. However, materials which are commonly used for sub-surface flow CWs, i.e., washed gravel or crushed rock, provide very low capacity for sorption and precipitation [2,48]. Recently, manufactured filtration materials such as LECA (light weight clay aggregates) or by- and waste-products such as furnace steel slags, have been tested in constructed wetlands $[98,99]$. The removal of phosphorus is very high with these substrates, but it is important to realize that sorption and precipitation are saturable processes and the sorption decreases over time.

Table 5. Treatment efficiency (Eff, in \%) of various types of constructed wetlands (CWs) for nitrogen and phosphorus. Inflow (In) and outflow (Out) concentrations in mg/L. HLR = hydraulic loading rate $(\mathrm{cm} / \mathrm{d}) . \mathrm{N}=$ number of $\mathrm{CWs} . *$ updated.

\begin{tabular}{|c|c|c|c|c|c|c|c|c|c|c|c|c|c|c|c|c|}
\hline \multirow{2}{*}{$\begin{array}{c}\text { Type of } \\
\text { CW } \\
\end{array}$} & \multirow[t]{2}{*}{ Ref. } & \multicolumn{5}{|c|}{$\mathbf{T P}$} & \multicolumn{5}{|c|}{$\mathbf{T N}$} & \multicolumn{5}{|c|}{$\mathbf{N H}_{4}-\mathbf{N}$} \\
\hline & & In & Out & Eff & HLR & $\mathbf{N}$ & In & Out & Eff & HLR & $\mathbf{N}$ & In & Out & Eff & HLR & $\mathbf{N}$ \\
\hline \multirow[t]{4}{*}{ FWS } & {$[2]^{*}$} & 14.7 & 9.7 & 34 & 5.4 & 52 & 42.6 & 23.5 & 45 & 4.9 & 29 & 30 & 16 & 48 & 5.4 & 40 \\
\hline & [42] & 4.0 & 1.8 & 49 & & 207 & 11.7 & 6.2 & 47 & & 192 & & & & & \\
\hline & [11] & 7.9 & 5.1 & 35 & 12.3 & 282 & 84 & 49.5 & 41 & 8.9 & 116 & 75 & 46 & 39 & 7.3 & 118 \\
\hline & [90] & 3.6 & 1.8 & 50 & 3.5 & 52 & 10.9 & 4.6 & 58 & 3.2 & 36 & 5.8 & 2.7 & 53 & 3.1 & 59 \\
\hline
\end{tabular}


Table 5. Cont.

\begin{tabular}{|c|c|c|c|c|c|c|c|c|c|c|c|c|c|c|c|c|}
\hline \multirow{2}{*}{$\begin{array}{c}\text { Type of } \\
\text { CW }\end{array}$} & \multirow[t]{2}{*}{ Ref. } & \multicolumn{5}{|c|}{$\mathbf{T P}$} & \multicolumn{5}{|c|}{ TN } & \multicolumn{5}{|c|}{$\mathbf{N H}_{4}-\mathbf{N}$} \\
\hline & & In & Out & Eff & HLR & $\mathbf{N}$ & In & Out & Eff & HLR & $\mathbf{N}$ & In & Out & Eff & HLR & $\mathbf{N}$ \\
\hline \multirow[t]{2}{*}{$\mathrm{HF}$} & [2] & 9.6 & 4.8 & 50 & 11.4 & 272 & 63 & 36 & 43 & 10.6 & 208 & 36 & 22 & 39 & 14.1 & 305 \\
\hline & [11] & & & & & & 54 & 36 & 33 & 7.6 & 123 & 40 & 28 & 30 & 7.0 & 213 \\
\hline VF & {$[2]^{*}$} & 10.3 & 4.5 & 56 & 8.2 & 118 & 73 & 41 & 43 & 9.1 & 99 & 56 & 14.9 & 73 & 8.4 & 129 \\
\hline
\end{tabular}

Removal of total nitrogen (Table 5) is also usually low due to low nitrification in water-saturated HF constructed wetlands and low or zero denitrification in FWS and VF CWs, respectively $[2,11,48]$. In FWS CWs nitrogen is removed via nitrification in aerobic water column and subsequent denitrificaton in anoxic litter layer on the bed surface. Volatilization may be a significant route for nitrogen removal in constructed wetlands with open water surface where algal assemblages can create high $\mathrm{pH}$ values during the day through their photosynthetic activity [46]. In vertical-flow constructed wetlands, very high nitrification proceeds but, because of entirely aerobic conditions in the vertical bed, no denitrification takes place [76]. In order to achieve effective removal of total nitrogen VF CWs could be combined with HF CWs which, in contrast, do not nitrify but provide suitable conditions for reduction of nitrate formed during nitrification in VF beds $[2,11,48,76]$. Plant uptake in all types of constructed wetlands is effective only when plants are harvested, but the amount sequestered in the aboveground biomass is usually very low and does not exceed $10 \%$ of the inflow nutrient load [2].

More details on treatment performance of constructed wetlands for various types of wastewater could be found elsewhere $[2,11,96]$.

\section{Costs}

The basic investment costs for constructed wetlands include land, site investigation, system design, earthwork, liners, filtration (HF and VF CWs) or rooting (FWS CWs) media, vegetation, hydraulic control structures and miscellaneous costs (e.g., fencing, access roads) [41]. However, the proportions of individual costs vary widely in different parts of the world. Also, larger systems demonstrate greater economies for scale [41]. For example, Vymazal and Kröpfelová [2] summarized available data from HF CWs in U.S., Czech Republic, Portugal, Spain and Portugal and found out that excavation costs varied between 7 and $27.4 \%$ of the total capital cost, while gravel varied between 27 and 53\%, liner (13-33\%), plants (2-12\%), plumbing (6-12\%), control structures (3.1-5.7\%) and miscellaneous $(1.8-12 \%)$. The total investment costs vary even more, and the cost could be as low as 29 USD per $\mathrm{m}^{2}$ in India [100] or 33 USD per $\mathrm{m}^{2}$ in Costa Rica [101], or as high as 257 EUR per $\mathrm{m}^{2}$ in Belgium [102]. In general, the capital costs for subsurface flow constructed wetlands are about the same as for conventional treatment systems. The capital costs for FWS CWs are usually less than for subsurface flow systems mainly because the cost for media is limited to rooting soil on the bottom of the beds.

Constructed wetlands have very low operation and maintenance costs, including pumping energy (if necessary), compliance monitoring, maintenance of access roads and berms, pretreatment maintenance (including regular cleaning of screens and emptying septic or Imhoff tank and grit chambers), vegetation harvesting (if applicable) and equipment replacement and repairs. The basic costs are much lower than those for competing concrete and steel technologies, by a factor of 
2-10 [2,11]. In addition, because wetlands have a higher rate of biological activity than most ecosystems, they can transform many of the common pollutants that occur in conventional wastewaters into harmless byproducts or essential nutrients that can be used for additional biological productivity. These transformations are accomplished by virtue of the wetland's land area, with the inherent natural environmental energies of sun, wind, soil, plants, and animals. Because of the natural environmental energies at work in constructed treatment wetlands, minimal fossil fuel energy and chemicals are typically needed to meet treatment objectives [11].

\section{Conclusions}

Constructed treatment wetlands have evolved during the last five decades into a reliable treatment technology which can be applied to all types of wastewater including sewage, industrial and agricultural wastewaters, landfill leachate and stormwater runoff. Pollution is removed through the processes which are common in natural wetlands but, in constructed wetlands, these processes proceed under more controlled conditions. All types of constructed wetlands are very effective in removing organics and suspended solids, whereas removal of nitrogen is lower but could be enhanced by using a combination of various types of CWs. Removal of phosphorus is usually low unless special media with high sorption capacity are used. Constructed wetlands require very low or zero energy input and, therefore, the operation and maintenance costs are much lower compared to conventional treatment systems. In addition to treatment, constructed wetlands are often designed as dual- or multipurpose ecosystems which may provide other ecosystems services such as flood control, carbon sequestration or wildlife habitat.

\section{Acknowledgements}

The study was supported by grants No. 206/06/0058 "Monitoring of Heavy Metals and Selected Risk Elements during Wastewater Treatment in Constructed Wetlands" from the Czech Science Foundation, No. 2B06023 "Development of Mass and Energy Flows Evaluation in Selected Ecosystems" from the Ministry of Education, Youth and Sport of the Czech Republic and No. QH81170 Complex Evaluation of the Effect of Area Protection on Important Water Management Localities from the Ministry of Agriculture of the Czech Republic.

\section{References}

1. Brix, H.; Schierup, H.-H. The use of macrophytes in water pollution control. $A M B I O$ 1989, 18, 100-107.

2. Vymazal, J.; Kröpfelová, L. Wastewater Treatment in Constructed Wetlands with Horizontal Sub-Surface Flow; Springer: Dordrecht, The Netherlands, 2008.

3. Seidel, K. Die Flechtbinse Scirpus lacustris. In Ökologie, Morphologie und Entwicklung, ihre Stellung bei den Volkern und ihre wirtschaftliche Bedeutung; Schweizerbart'sche Verlagsbuchnadlung: Stuttgart, Germany, 1955; pp. 37-52.

4. Seidel, K. Reinigung von Gewässern durch höhere Pflanzen. Naturwissenschaften 1966, 53, 289-297. 
5. Seidel, K. Macrophytes and Water Purification. In Biological Control of Water Pollution; Tourbier, J., Pierson, R.W., Eds.; Pennsylvania University Press: Philadelphia, PA, USA, 1976; pp. 109-122.

6. Seidel, K. Zur Problematik der Keim-und Pflanzengewasser. Verh. Internat. Verein. Limnol. 1961, 14, 1035-1039.

7. De Jong, J. The Purification of Wastewater with the Aid of Rush or Reed Ponds. In Biological Control of Water Pollution; Tourbier, J., Pierson, R.W., Eds.; Pennsylvania University Press: Philadelphia, PA, USA, 1976; pp. 133-139.

8. Ewel, K.C.; Odum, H.T. Cypress Swamps; University of Florida Press: Gainesville, FL, USA, 1984.

9. Odum, H.T.; Ewel, K.C.; Mitsch, W.J.; Ordway, J.W. Recycling Treated Sewage through Cypress Wetlands in Florida. In Wastewater Renovation and Reuse; D'Itri, F.M., Ed.; Marcel Dekker: New York, NY, USA, 1977; pp. 35-67.

10. Kadlec, R.H.; Tilton, D.L. The use of freshwater wetlands as a tertiary wastewater treatment alternative. CRC Crit. Rev. Env. Control 1979, 9, 185-212.

11. Kadlec, R.H.; Wallace, S.D. Treatment Wetlands, 2nd ed.; CRC Press: Boca Raton, FL, USA, 2008.

12. Vymazal, J. Horizontal sub-surface flow and hybrid constructed wetlands for wastewater treatment. Ecol. Eng. 2005, 25, 478-490.

13. Kadlec, R.H. Overview: Surface Flow Constructed Wetlands. In Proceedings of the 4th International Conference Wetland Systems for Water Pollution Control; ICWS Secretariat: Guangzhou, China, 1994; pp. 1-12.

14. QDNR (Queensland Department of Natural Resources). Guidelines for Using Freewater Surface Constructed Wetlands to Treat Municipal Sewage; QDNR: Brisbane, Australia, 2000.

15. Vymazal, J.; Greenway, M.; Tonderski, K.; Brix, H.; Mander, Ü. Constructed Wetlands for Wastewater Treatment. In Wetlands and Natural Resource Management; Ecological Studies. Verhoeven, J.T.A., Beltman, B., Bobbink, R., Whigham, D.F., Eds.; Springer Verlag: Berlin, Germany, 2006; Volume 190, pp. 69-94.

16. DuBowy, P.; Reaves, P. Constructed Wetlands for Animal Waste Management; Conservation Technology Information Center, U.S. Dept. of Agriculture Soil Conservation Service, U.S. EPA Region V and Purdue University Agric. Res. Program: Lafayette, IN, USA, 1994.

17. Knight, R.L.; Payne, V.W.E., Jr.; Borer, R.E.; Clarke, R.A., Jr.; Pries, J.H. Constructed wetlands for livestock wastewater management. Ecol. Eng. 2000, 15, 41-55.

18. Knight, R.L.; Clarke, R.A., Jr.; Bastian, R.K. Surface flow (sf) treatment wetlands as a habitat for wildlife and humans. Wat. Sci. Tech. 2000, 44, 27-38.

19. Tanner, C.C.; Nguyen, M.L.; Sukias, J.P.S. Nutrient removal by a constructed wetland treating subsurface drainage from a grazed dairy pasture. Agric. Ecosyst. Environ. 2005, 105, 145-162.

20. Higgins, M.J.; Rock, C.A.; Bouchard, R.; Wengrezynek, B. Controlling Agricultural Run-off by the Use of Constructed Wetlands. In Constructed Wetlands for Water Quality Improvement; Moshiri, G.A., Ed.; Lewis Publishers: Boca Raton, FL, USA, 1993; pp. 359-367. 
21. Bavor, H.J.; Davies, C.M.; Sakadevan, K. Stormwater treatment: do constructed wetlands yield improved pollutant management performance over a detention pond system? Wat. Sci. Tech. 2001, 44, 565-570.

22. Pontier, H.; Williams, J.B.; May, E. Progressive changes in water and sediment quality in a wetland system for control of highway runoff. Sci. Tot. Environ. 2004, 319, 215-224.

23. Thorén, A.K.; Legrand, C.; Hermann, J. Transport and transformation of de-icing urea from airport runways in a constructed wetland system. Wat. Sci. Tech. 2003, 48, 283-290.

24. Karathanasis, A.D.; Johnson, C.M. Metal removal potential by three aquatic plants in an acid mine drainage wetland. Mine Water Environ. 2003, 22, 22-30.

25. Ramírez Masferrer, J.A. Passive treatment of acid mine drainage at the La Extranjera Mine (Puertollano, Spain). Mine Water Environ. 2002, 21, 111-113.

26. Kiessig, G.; Küchler, A.; Kalin, M. Passive Treatment of Contaminated Water from Uranium Mining and Milling. In Constructed and Riverine Wetlands for Optimal Control of Wastewater at Catchment Scale; Mander, Ü., Vohla, C, Poom, A., Eds.; University of Tartu: Tartu, Estonia, 2003; p. 116.

27. O'Sullivan, A.D.; Moran, B.M.; Otte, M.L. Accumulation and fate of contaminants ( $\mathrm{Zn}, \mathrm{Pb}, \mathrm{Fe}$ and $\mathrm{S}$ ) in substrates of wetlands constructed for treating mine wastewater. Water Air Soil Pollut. 2004, 157, 345-364.

28. Sobolewski, A. Metal species indicate the potential of constructed wetlands for long-term treatment of mine drainage. J. Ecol. Eng. 1996, 6, 259-271.

29. Litchfield, D.K.; Schatz, D.D. Constructed Wetlands for Wastewater Treatment at Amoco Oil Company's Mandan, North Dakota refinery. In Constructed Wetlands for Wastewater Treatment; D.A. Hammer, Ed.; Lewis Publishers: Chelsea, MI, USA, 1989; pp. 233-237.

30. Lakatos, G. Hungary. In Constructed Wetlands for Wastewater Treatment in Europe; Vymazal, J., Brix, H., Cooper, P.F., Green, M.B., Haberl, R., Eds.; Backhuys Publishers: Leiden, The Netherlands, 1998; pp. 191-206.

31. Tettleton, R.P.; Howell, F.G.; Reaves, R.P. Performance of a Constructed Marsh in the Tertiary Treatment of Bleach Kraft Pulp Mill Effluent: Results of a 2-year Pilot Project. In Constructed Wetlands for Water Quality Improvement; Moshiri, G.A., Ed.; CRC Press/Lewis Publishers: Boca Raton, FL, USA, 1993; pp. 437-440.

32. Tilley, D.R.; Badrinarayanan, H.; Rosati, R.; Son, J. Constructed wetlands as recirculation filters in large-scale shrimp aquaculture. Aquacultural Eng. 2002, 26, 81-109.

33. Benyamine, M.; Bäckström, N.; Sandén, P. Multi-objective environmental management in constructed wetlands. Environ. Monitor. Assess. 2004, 90, 171-185.

34. Mæhlum, T. Treatment of landfill leachate in on-site lagoons and constructed wetlands. In Proceedings of the 4th International Conference Wetland Systems for Water Pollution Control; Guangzhou, China, 1994; pp. 553-559.

35. Johnson, K.D.; Martin, C.D.; Moshiri, G.A.; McCrory, W.C. Performance of a Constructed Wetland Leachate Treatment System at the Chunchula landfill, Mobile County, Alabama. In Constructed Wetlands for the Treatment of Landfill Leachates; Mulamoottil, G., McBean, E.A., Rovers, F., Eds.; CRC Press/Lewis Publishers: Boca Raton, FL, USA, 1999; pp.57-70. 
36. Tonderski, K.S.; Grönlund, E.; Billgren, C. Management of Sugar Effluent in the Lake Victoria Region. In Proceedings of the Workshop Wastewater treatment in Wetlands. Theoretical and Practical Aspects; Toczyłowska, I., Guzowska, G., Eds.; Gdańsk University of Technology Printing Office: Gdansk, Poland, 2005; pp. 177-184.

37. Kapellakis, I.E.; Tsagarakis, K.P.; Angelakis, A.N. Performance of Free Water Surface Constructed Wetlands for Olive Mill Wastewater Treatment. In Proceedings of the 9th International Conference on Wetland Systems for Water Pollution Control; ASTEE: Lyon, France, 2004; pp. 113-120.

38. Masbough, A.; Frankowski, K.; Hall, K.J.; Duff, S.J.B. The effectiveness of constructed wetland for treatment of woodwaste leachate. Ecol. Eng. 2005, 25, 552-566.

39. Maine, M.A.; Sune, N.; Hadad, H.; Sánchez, G.; Bonetto, C. Nutrient and metal removal in a constructed wetland for waste-water treatment from a metallurgic industry. Ecol. Eng. 2006, 26, 341-347.

40. Maine, M.A.; Sune, N.; Hadad, H.; Sánchez, G.; Bonetto, C. Removal efficiency of a constructed wetland for wastewater treatment according to vegetation dominance. Chemosphere 2007, 68, 1105-1113.

41. Wallace, S.D.; Knight, R.L. Small Scale Constructed Wetland Treatment Systems. Feasibility, Design Criteria, and O\&M Requirements; Water Environ. Res. Foundation: Alexandria, VA, USA, 2006.

42. U.S. EPA. Constructed Wetlands Treatment of Municipal Wastewater. Manual. EPA 625/R-99/010; U.S. Environmental Protection Agency: Cincinnati, OH, USA, 2000.

43. Cooper, P.F.; Job, G.D.; Green, M.B.; Shutes, R.B.E. Reed Beds and Constructed Wetlands for Wastewater Treatment; WRc Publications: Medmenham, UK, 1996.

44. Vymazal, J. Types of Constructed Wetlands for Wastewater Treatment: Their Potential for Nutrient Removal. In Transformations of Nutrients in Natural and Constructed Wetlands; Vymazal, J., Ed.; Backhuys Publishers: Leiden, The Netherlands, 2001; pp. 1-93.

45. Kickuth, R. Degradation and Incorporation of Nutrients from Rural Wastewater by Plant Hydrosphere under Limnic Conditions. In Utilization of Manure by Land Spreading; Comm. Europ. Commun, EUR 5672e: London, U.K, 1977; pp. 335-343.

46. Brix, H.; Schierup, H.-H. Sewage treatment in constructed wetlands-Danish experience. Wat. Sci. Tech. 1989, 21, 1665-1668.

47. Vymazal, J.; Kröpfelová, L. Is Concentration of Dissolved Oxygen a Good Indicator of Processes in Filtration Beds of Horizontal-flow Constructed Wetlands? In Wastewater Treatment, Plant Dynamics and Management; Vymazal, J., Ed.; Springer: Dordrecht, The Netherlands, 2008; pp. 311-317.

48. Vymazal, J. Removal of nutrients in various types of constructed wetlands. Sci. Tot. Environ. 2007, 380, 48-65.

49. Brix, H. Functions of macrophytes in constructed wetlands. Wat. Sci. Tech. 1994, 29, 71-78.

50. Langergraber, G.; Giraldi, D.; Mena, J.; Meyer, D.; Peña, M.; Toscano, A.; Brovelli, A.; Korkusuz, E.A. Recent developments in numerical modelling of subsurface flow constructed wetlands. Sci. Tot. Environ. 2009, 407, 3931-3943. 
51. Rousseau, D.P.L.; Vanrolleghem, P.A.; De Pauw, N. Model-based design of horizontal subsurface flow constructed wetlands: a review. Water Res. 2004, 38, 1484-1493.

52. Wallace, S.D. On-site Remediation of Petroleum Contact Wastes Using Subsurface-flow Wetlands. In Wetlands and Remediation II; Nehring, K.W., Brauning, S.E., Eds.; Battelle Press: Columbus, OH, USA, 2002; pp. 125-132.

53. Ji, G.; Sun, T.; Zhou, Q.; Sui, X.; Chang, S.; Li, P. Constructed subsurface slow wetland for treating heavy oil-produced water of the Liaohe Oilfield in China. Ecol. Eng. 2002, 18, 459-465.

54. Sands, Z.; Gill, L.S.; Rust, R. Effluent Treatment Reed Beds: Results after Ten Years of Operation. In Wetlands and Remediation; Means, J.F., Hinchee, R.E., Eds.; Battelle Press: Columbus, OH, USA, 2000; pp. 273-279.

55. Thut, R.N. Feasibility of Treating Pulp Mill Effluent with a Constructed Wetland. In Constructed Wetlands for Water Quality Improvement; Moshiri, G.A., Ed.; Lewis Publishers: Boca Raton, FL, USA, 1993; pp. 441-447.

56. Poggi-Varaldo, H.M.; Gutiérez-Saravia, A.; Fernández-Villagómez, G.; Martínez-Pereda, P.; Rinderknecht-Seijas, N. A full-scale System with Wetlands for Slaughterhouse Wastewater Treatment. In Wetlands and Remediation II; Nehring, K.W., Brauning, S.E., Eds.; Battelle Press: Columbus, OH, USA, 2002; pp. 213-223.

57. Lavigne, R.L.; Jankiewicz, J. Artificial Wetland Treatment Technology and It's Use in the Amazon River Forests of Ecuador. In Proceedings of the 7th International Conference on Wetland Systems for Water Pollution Control; University of Florida: Gainesville, FL, USA, 2000; pp. 813-820.

58. Davies, T.H.; Cottingham, P.D. The Use of Constructed Wetlands for Treating Industrial Effluent. In Proceedings of the 3rd International Conference on Wetland Systems in Water Pollution Control; IAWQ and Australian Water and Wastewater Association: Sydney, Australia, 1992; pp. 53.1-53.5.

59. Calheiros, C.S.C.; Rangel, A.O.S.S.; Castro, P.K.L. Constructed wetland systems vegetated with different plants applied to the treatment of tannery wastewater. Water Res. 2007, 41, 1790-1798.

60. Vrhovšek, D.; Kukanja, V.; Bulc, T. Constructed wetland (CW) for industrial waste water treatment. Water Res. 1996, 30, 2287-2292.

61. Mantovi, P.; Marmiroli, M.; Maestri, E.; Tagliavini, S.; Piccinini, S.; Marmiroli, N. Application of a horizontal subsurface flow constructed wetland on treatment of dairy parlor wastewater. Bioresour. Technol. 2003, 88, 85-94.

62. Billore, S.K.; Singh, N.; Ram, H.K.; Sharma, J.K.; Singh, V.P.; Nelson R.M.; Das, P. Treatment of a molasses based distillery effluent in a constructed wetland in central India. Water Sci. Tech. 2001, 44, 441-448.

63. Masi, F.; Conte, G.; Martinuzzi, N.; Pucci, B. Winery High Organic Content Wastewaters Treated by Constructed Wetlands in Mediterranean climate. In Proceedings of the 8th International Conference on Wetland Systems for Water Pollution Control; University of Dar-es-Salaam: Dar-es-Salaam, Tanzania, 2002; pp. 274-282.

64. Finlayson, M.; Chick, A.; von Oertzen, I.; Mitchell, D. Treatment of piggery effluent by an aquatic plant filter. Biol. Wastes 1987, 19, 179-196. 
65. Strusevičius, Z.; Strusevičiene, S.M. Investigations of Wastewater Produced on Cattle-breeding Farms and its Treatment in Constructed Wetlands. In Proceedings of the International Conference on Constructed and Riverine Wetlands for Optimal Control of Wastewater at Catchment Scale; Mander, Ü., Vohla, C., Poom, A., Eds.; University of Tartu, Institute of Geography: Tartu, Estonia, 2003; pp. 317-324.

66. Comeau, Y.; Brisson, J.; Réville, J.-P.-; Forget, C.; Drizo, A. Phosphorus removal from trout farm effluents by constructed wetlands. Wat. Sci. Tech. 2001, 44, 55-60.

67. Schulz, C.; Gelbrecht, J.; Rennert, B. Treatment of rainbow trout farm effluents in constructed wetland with emergent plants and subsurface horizontal water flow. Aquaculture 2003, 217, 207-221.

68. Drizo, A.; Twohig, E.; Weber, D.; Bird, S.; Ross, D. Constructed Wetlands for Dairy Effluent Treatment in Vermont: Two Years of Operation. In Proceedings of the 10th International Conference on Wetland Systems for Water Pollution Control; MAOTDR 2006: Lisbon, Portugal, 2006; pp. 1611-1621.

69. Kern, J.; Brettar, I. Nitrogen Turnover in a Subsurface Constructed Wetland Receiving dairy Farm Wastewater. In Treatment Wetlands for Water Quality Improvement; Pries, J., Ed.; CH2M Hill Canada Limited: Waterloo, Canada, 2002; pp. 15-21.

70. Perdomo, S.; Bangueses, C.; Fuentes, J.; Castro, J.; Acevedo, H.; Michelotti, C. Constructed Wetlands: A More Suitable Alternative for Wastewater Purification in Uruguayn Dairy Processing Industry. In Proceedings of the 7th International Conference on Wetland Systems for Water Pollution Control; Reddy, K.R., Kadlec, R.H., Eds., University of Florida and IWA: Gainesville, FL, USA, 2000; pp. 1407-1415.

71. Revitt, D.M.; Shutes, R.B.E.; Jones, R.H.; Forshaw, M.; Winter, B. The performance of vegetative treatment systems for highway runoff during dry and wet conditions. Sci. Tot. Environ. 2004, 334-335, 261-270.

72. Karrh, J.D.; Moriarty, J.; Kornue, J.J.; Knight, R.L. Sustainable Management of Aircraft Anti/de-icing Process Effluents using a Subsurface-flow Treatment Wetland. In Wetlands and Remediation II; Nehring, W., Brauning, S.E., Eds.; Battelle Press: Columbus, OH, USA, 2002; pp. 187-195.

73. Headley, T.R.; Huett, D.O.; Davison, L. The removal of nutrients from plant nursery irrigation runoff in subsurface horizontal-flow wetlands. Wat. Sci. Tech. 2001, 44, 77-84.

74. Wojciechowska, E.; Obarsa-Pempkowiak, H. Performance of Reed Beds Supplied with Municipal Landfill Lechate. In Wastewater Treatment, Plant Dynamics and Management; Vymazal, J., Ed.; Springer: Dordrecht, The Netherlands, 2008.

75. Seidel, K. Neue Wege zur Grundwasseranreicherung in Krefeld, Vol. II. Hydrobotanische Reinigungsmethode. GWF Wasser/Abwasser 1965, 30, 831-833.

76. Brix, H. The use of vertical flow constructed wetlands for on-site treatment of domestic waste water: New Danish guidelines. Ecol. Eng. 2005, 25, 491-500.

77. Cooper, P.F. A review of the design and performance of vertical flow and hybrid reed bed treatment systems. Wat. Sci. Tech. 1999, 40, 1-9.

78. Weedon, C.N. Compact vertical flow reed beds: design rationale and early performance. IWA Macrophytes Newsletter 2001, 23, 12-20. 
79. Molle, P.; Liénard, A.; Boutin, C.; Merlin, G.; Iwema, A. How to treat raw sewage with constructed wetlands: an overview of French systems. Wat. Sci. Tech. 2005, 51, 11-21.

80. Aslam, M.M.; Malik, M.; Baig, M.A.; Qazi, I.A.; Iqbal, J. Treatment performance of compost-based and gravel-based vertical flow wetlands operated identically for refinery wastewater treatment in Pakistan. Ecol. Eng. 2007, 30, 34-42.

81. Lindenblatt, C. Planted Soil Filters with Activated Pretreatment for Composting-place Wastewater Treatment. In Proceedings of the Workshop Wastewater Treatment in Wetlands. Theoretical and Practical Aspects; Toczyłowska, I., Guzowska, G., Eds.; Gdańsk University of Technology Printing Office: Gdansk, Poland, 2005; pp. 87-93.

82. McGill, R.; Basran, D.; Flindall, R.; Pries, J. Vertical-flow constructed wetland for the treatment of glycol-laden stormwater runoff at Lester B. Pearson International Airport. In Proceedings of the 7th International Conference on Wetland Systems for Water Pollution Control; University of Florida and IWA: Lake Buena Vista, FL, USA, 2000; pp. 1080-1081.

83. Veenstra, S. The Netherlands. In Constructed Wetlands for Wastewater Treatment in Europe; Vymazal, J., Brix, H., Cooper, P.F., Green, M.B., Haberl, R., Eds.; Backhuys Publishers: Leiden, The Netherlands, 1998; pp. 289-314.

84. Kern, J.; Idler, C. Treatment of domestic and agricultural wastewater by reed bed systems. Ecol. Eng. 1999, 12, 13-25.

85. Salati, E. Edaphic-phytodepuration: a New Approach to Wastewater Treatment. In Aquatic Plants for Water Treatment and Resource Recovery; Reddy, K.R., Smith, W.H., Eds.; Magnolia Publishing: Orlando, FL, USA, 1987; pp. 199-208.

86. Cooper, P.F. The performance of vertical flow constructed wetland systems with special reference to the significance of oxygen transfer and hydraulic loading rates. Wat. Sci. Tech. 2005, $51,81-90$.

87. Vymazal, J. Constructed wetlands with horizontal sub-surface flow and hybrid systems for wastewater treatment. Ecol. Eng. 2005, 25, 478-490.

88. Boutin, C. Domestic wastewater treatment in tanks planted with rooted macrophytes: case study, description of the system, design criteria, and efficiency. Wat. Sci. Tech. 1987, 19, 29-40.

89. Burka, U.; Lawrence, P. A New Community Approach to Wastewater treatment with Higher Water Plants. In Constructed Wetlands in Water Pollution Control; Cooper, P.F.; Findlater, B.C., Eds.; Pergamon Press: Oxford, UK, 1990; pp. 359-371.

90. Bulc, T.G. Long term performance of a constructed wetland for landfill leachate treatment. Ecol. Eng. 2006, 26, 365-374.

91. Kinsley, C.B.; Crolla, A.M.; Kuyucak, N.; Zimmer, M.; Lafleche, A. Nitrogen Dynamics in a Constructed Wetland System Treating Landfill Leachate. In Proceedings of the 10th International Conference on Wetland Systems for Water Pollution Control; MAOTDR: Lisbon, Portugal, 2006; pp. 295-305.

92. Reeb, G.; Werckmann, M. First Performance Data on the Use of Two Pilot-constructed Wetlands for Highly Loaded Non-domestic Sewage. In Natural and Constructed Wetlands: Nutrients, Metals and Management; Vymazal, J., Ed.; Backhuys Publishers: Leiden, The Netherlands, 2005; pp. 43-51. 
93. Soroko, M. Treatment of Wastewater from Small Slaughterhouse in Hybrid Constructed Wetlands System. In Proceedings of the Workshop Wastewater Treatment in Wetlands. Theoretical and Practical Aspects; Toczyłowska, I., Guzowska, G., Eds.; Gdańsk University of Technology Printing Office: Gdansk, Poland, 2005; pp. 171-176.

94. Lin, Y.F.; Jing, S.R.; Lee, D.Y.; Wang, T.W. Nutrient removal from aquaculture wastewater using a constructed wetlands system. Aquaculture 2002, 209, 169-184.

95. Lin, Y.F.; Jing, S.R.; Lee, D.Y. The potential use of constructed wetlands in a recirculating aquaculture system for shrimp culture. Environ. Poll. 2003, 123, 107-113.

96. Kadlec, R.H.; Knight, R.L. Treatment Wetlands; CRC Press/Lewis Publishers: Boca Raton, FL, USA, 1996.

97. Richardson, C.J. Mechanisms controlling phosphorus retention capacity in freshwater wetlands. Science 1985, 228, 1424-1427.

98. Vohla, C.; Põldvere, E.; Noorvee, A.; Kuusemets, V.; Mander, Ü. Alternative filter media for phosphorus removal in a horizontal subsurface flow constructed wetland. J. Environ. Sci. Health 2005, 40, 1251-1264.

99. Jenssen, P.D.; Krogstad, T. Design of Constructed Wetlands Using Phosphorus Sorbing Lightweight Aggregate (LWA). In Constructed Wetlands for Wastewater Treatment in Cold Climates; Mander, Ü., Jenssen, P.D., Eds.; WIT Press: Southampton, UK, 2003; pp. 259-271.

100. Billore, S.K.; Singh, N.; Sharma, J.K.; Dass, P.; Nelson, R.M. Horizontal subsurface flow gravel bed constructed wetland with Phragmites karka in central India. Wat. Sci. Tech. 1999, 40, 173-171.

101. Dallas, S.; Scheffe, B.; Ho, G. Reedbeds for greywater treatment - case study in Santa ElenaMonteverde, Costa Rica, Central America. Ecol. Eng. 2004, 23, 55-61.

102. Rousseau, D.P.L.; Vanrolleghem, P.A.; De Pauw, N. Constructed wetlands in Flanders: a performance analysis. Ecol. Eng. 2004, 23, 151-163.

(C) 2010 by the authors; licensee MDPI, Basel, Switzerland. This article is an open access article distributed under the terms and conditions of the Creative Commons Attribution license (http://creativecommons.org/licenses/by/3.0/). 